\title{
高層建築物での順次避難における階段室内の流動状況と滞留発生に関する研究 - 全館避難訓練時の行動実態観測に基づく分析と考察 - \\ STUDY ON FLOW AND CONGESTION IN STAIRCASES DURING PHASED EVACUATION IN A HIGH-RISE BUILDING
}

- Analysis based on the observational data of a real total evacuation drill -

門倉博 之*, 関澤 愛**, 佐野友紀 ${ }^{* * *}$, 藤井皓介****

\section{Hiroyuki KADOKURA, Ai SEKIZAWA, Tomonori SANO and Kosuke FUIII}

\begin{abstract}
If a fire or other serious emergency occurs in a high-rise building, all occupants would be forced to evacuate the building under such an extreme event. Also, it is quite probable that many occupants in the building start to evacuate at the same time on this occasion. Further, the staircase would become very congested, if all occupants try to evacuate via a limited number of staircases concurrently. In such a case, it may cause considerable delay of the evacuation time or influence on walking speed of evacuees. To cope with this kind of simultaneous total evacuation, there is a method known as "phased evacuation", where occupants on a fire origin floor and the floor above will evacuate first and followed by other occupants in different floors to avoid congestion in the staircase. However, it is unclear how the phased evacuation is more efficient than simultaneous total evacuation, because there have been limited studies and data concerning this method of evacuation. To explore the potential availability of phased evacuation, this study analyzes the data obtained by video recording and measuring movement of evacuees during a total evacuation drill conducted in a high-rise office building in Tokyo.
\end{abstract}

Keywords: phased evacuation, total evacuation drill, observational data, stairs, congestion 順次避難，全館避難訓練，実測データ，階段室，滞留

\section{1. はじめに}

2001 年に米国ニューヨーク市で発生した世界貿易センタービルの 倒壊テロ事件でもみられたように、高層建築物において大規模な火 災や非常事態が発生したときに、在館者が全館避難を強いられる場 合のあることが現実となっている。全館避難の場合、一斉避難では 階段内の混雑が予想されるために、一般的には火災発生階及びその 直上階が優先的に避難し、他の階はそのあと避難する順次避難が考 えられている。順次避難計画については、(1)階段室内では上階から と階避難者との合流などによる混雑を避ける、(2)避難時間全体をで きるだけ最小化することが重要となる。しかしながら、火災発生階 との関係で、どのような順次避難計画が、火災安全上、また避難完 了時間上、最も効率的であるのかの検証については、実際の順次避 難の実測データが少ないため、十分に実施されてこなかったのが現 状である。

筆者らは、東京都内のある 25 階建て高層事務所ビルにおいて実施 された順次避難による全館避難訓練について、過去 6 回（2007 年、 2008 年、2010、2011 年、2012 年、2013 年実施）の実測調査 ${ }^{12) 33}$ を
行い、各避難訓練について階段室にビデオカメラを設置して階段室 内の避難訓練参加者の流動状況の観測を行なった。また、各階に実 験班のメンバーを配置し、群集と一緒に行動することによって、階 段室内における避難集団の移動歩行についての実測調查を行い、流 動分析を行ってきた。

既往関連研究では、順次避難に関するものとして、J. L. Pauls に よる一斉避難と順次避難の概念についての報告 ${ }^{4) 5}$ )があるが、順次 避難に関する実測結果は見られない。また、階段室内の滞留に関す るものとして、北後ら ${ }^{6)}$ 、あるいは佐野ら ${ }^{7)}$ の先行研究例がある。 これらの研究では、1 層の階段室において、2 群集の合流を実験的に 行い、踊り場における合流比、群集密度と歩行速度の関係式を算出 しているが、複層数の階における合流の影響や階段 1 層全体につい て分析したものではない。

筆者らの調查は、25 階建て事務所ビルにおける 25 層全層にわた って毎回 1,000 名以上の参加によって行われる全館の順次避難訓練 を実測したものであり、この観測結果は複数層にわたる実際に近い 階段室内の流動状況を知る上で非常に貴重なデータである。

\footnotetext{
* (株)東急総合研究所 修士(国際情報通信学)

** 東京理科大学大学院国際火災科学研究科 教授.工博

*** 早稲田大学人間科学学術院 教授・博士 (工学)

**** 早稲田大学大学院人間科学研究科 博士後期課程 · 修士 $($ 人間科学)
}

Tokyu Research Institute, Inc. M of Sciences in GITS.

Prof., Tokyo University of Science, Dr. Eng.

Prof., Waseda University, Dr. Eng.

Waseda University, M.A. in Human Sciences 
本研究は、多人数が参加する全館避難訓練において、最も参加者 の多かった 2012 年の実測調査について、訓練参加者の階段室内の流 動状況および降下軌跡を把握するとともに、階段室内で生じる滞留 発生要因について考察を行ったものである。

\section{2. 高層建築物の避難訓練調査の概要 \\ 2. 1 避難訓練の概要}

対象建物は、地上 25 階建ての高層建築物であり、主に事務所を用 途とする。避難訓練は、4 階の蝔房を出火階とした全館避難である。 避難方法は、順次避難とし、

・I フェーズ : 出火階とその上階「4・5・6 階」

・II フェーズ : 火災階に近い上階と最上層階「7〜12、21〜25 階」

・IIIフェーズ : 火災階から遠い上層階「3、13〜20 階」

のフェーズ毎に、防災センターの館内放送による避難開始の指示に 従い行われた（図 1)。避難放送は、実施年毎に避難開始時刻と放送 文を改善しながら実施している。避難経路は、各階より南北の階段 2 系統を使用し、1 階屋外の建物前広場までとしている。本調査では、 南側の階段のみを観測対象とした。

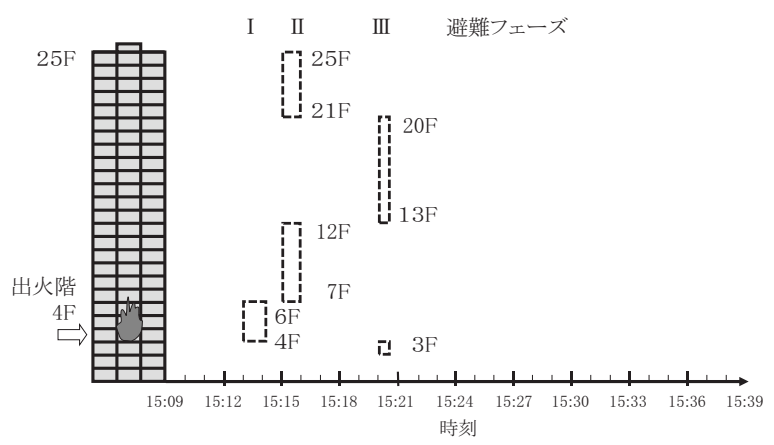

図 1 順次避難計画における避難開始フェーズ

注）図中の破線は避難開始階と避難放送時間の範囲を表す。

\section{2 訓練の観測方法}

対象建物（25 階建て）の階高は、1 階から 6 階までが 4.1m（うち $2 \sim 3$ 階 $4.4 \mathrm{~m}$ )、 7 階以上が $3.8 \mathrm{~m}$ である。階段は、階段幅 $1.2 \mathrm{~m}$ の折 り返し階段である。また、扉幅は、各階 $1 \mathrm{~m}$ である（表 1 、図 2 ）。 なお、図 2 に示寸階段室の各エリアについて、階踊り場（階の床部 にある扉のある踊り場のこと）、階段部（段床部のこと）、中間踊り 場（階の間にある扉のない踊り場のこと）と呼ぶものとする。

階段室内の訓練参加者の流動状況を記録するために、階踊り場 1 階から 24 階までビデオカメラを各 1 台（合計 24 台）設置して撮 影を行った。各ビデオカメラは、時刻を標準時間に秒単位で合わせ ており、全映像の同期が取れるようにした。分析にあたっては、ビ デオ映像の時刻をもとに時系列の流動状況を把握した。

また、避難集団の歩行移動を把握するため、被験者に集団の移動 に対するトレーサーの役割を与え、避難集団とともに一緒に行動さ せた。筆者ら実験班から参加した被験者は、大学生 20 名（男性 12 名、女性 8 名) である。これらの被験者を 6 階から 24 階に各 1 名（う ち 22 階のみ 2 名）配置し、各自ストップウォッチにより各階の階踊 り場位置間の歩行時間を測定した。避難開始に際しては、被験者は 階段室の附室にて待機し、各階の避難放送に従い階段室の附室に到
着した避難集団の中または最後尾にて避難を開始するものとした。 歩行時間の測定については、まず附室から階踊り場の床に片足が着 地したときを避難開始時間とし、一つ下の階踊り場に着地するまで の時間を避難開始階の歩行時間とした。以降、一層下の階踊り場に 着地するまでを階踊り場位置間の歩行時間とし、1 階のみ階段室出 口通過後に着地するまでとした。

\section{3. 訓練観測の結果}

\section{1 各階の訓練参加者数}

当日の建物在館者は 5,516 人である(通常約 6,000 名)。このうち、 避難訓練参加者は、高層ビル内の従業員 2,088 名であり、観測対象 とする南側階段を使用した避難者 (年齢 20〜50 代、男女比 7:3) は、 1,137 人（被験者 20 名を含む）であった。各階からの避難訓練参加 者のうち、11 階(148 名)、13 階(122 名)、14 階(106 名)が他の階に 比べ避難者が特に多かった（表 2 ）。

表 1 階段寸法

\begin{tabular}{|c|c|c|c|c|}
\hline 階 & 1 2 階 & 2 3階 & $3 \sim 7$ 階 & $7 \sim 25$ 階 \\
\hline 階高 & $4.1 \mathrm{~m}$ & $4.4 \mathrm{~m}$ & $4.1 \mathrm{~m}$ & $3.8 \mathrm{~m}$ \\
\hline 踏面 & \multicolumn{5}{|c|}{$280 \mathrm{~mm}$} \\
\hline 蹴上 & $171 \mathrm{~mm}$ & $170 \mathrm{~mm}$ & $171 \mathrm{~mm}$ & $173 \mathrm{~mm}$ \\
\hline 階段幅 & \multicolumn{5}{|c|}{$1.2 \mathrm{~m}$} \\
\hline
\end{tabular}

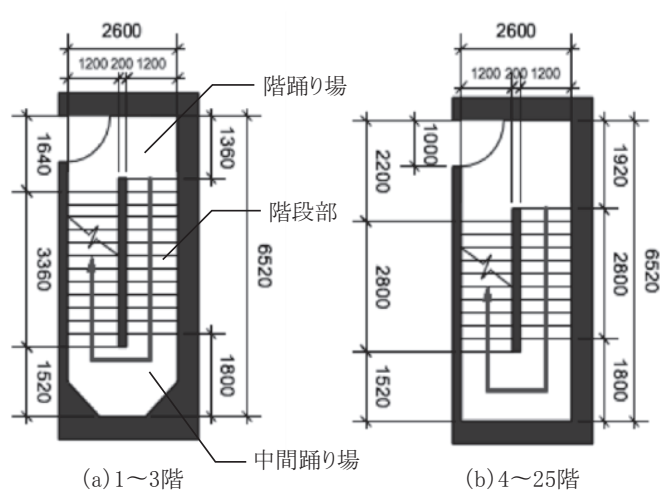

図 2 階段室の寸法 $(\mathrm{mm})$

表 2 各階の訓練参加者数

\begin{tabular}{|c|c|c|}
\hline フェーズ & 階数 & 訓練参加者数 (人) \\
\hline \multirow{4}{*}{ II } & 25 & 4 \\
\cline { 2 - 3 } & 24 & 73 \\
\cline { 2 - 3 } & 23 & 46 \\
\cline { 2 - 3 } & 22 & 63 \\
\cline { 2 - 3 } & 21 & 32 \\
\hline \multirow{4}{*}{ III } & 20 & 38 \\
\cline { 2 - 3 } & 19 & 4 \\
\cline { 2 - 3 } & 18 & 29 \\
\cline { 2 - 3 } & 17 & 47 \\
\cline { 2 - 3 } & 16 & 26 \\
\cline { 2 - 3 } & 15 & 25 \\
\cline { 2 - 3 } & 14 & 106 \\
\cline { 2 - 3 } & 13 & 122 \\
\hline \multirow{4}{*}{ II } & 12 & 70 \\
\cline { 2 - 3 } & 11 & 148 \\
\cline { 2 - 3 } & 10 & 97 \\
\cline { 2 - 3 } & 9 & 26 \\
\cline { 2 - 3 } & 8 & 1 \\
\cline { 2 - 3 } & 7 & 5 \\
\hline \multirow{4}{*}{ I } & 6 & 75 \\
\cline { 2 - 3 } & 5 & 29 \\
\cline { 2 - 3 } & 4 & 45 \\
\hline \multirow{4}{*}{ III } & 3 & 22 \\
\cline { 2 - 3 } & 2 & 4 \\
\hline \hline & 総数 & 1,137 \\
\hline
\end{tabular}




\section{2 被験者の階段室内の歩行速度}

階段降下にかかる歩行時間の実測結果にもとづいて、被験者の各 階の階踊り場間の歩行速度を算出した。図 3 は、避難訓練時におい て各階から避難を開始する被験者の歩行速度を表す。なお、歩行距 離は、階踊り場および中間踊り場では中央をコの字に結んだ距離と

し、段部では段鼻を斜めに結んだ斜め距離とした。

避難訓練時の群集内における被験者の歩行速度は、平均 $0.56 \mathrm{~m} /$ 秒

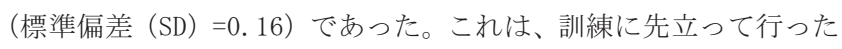
単独自由歩行による平均歩行速度 $0.96 \mathrm{~m} /$ 秒 $(\mathrm{SD}=0.10)$ に比べ約 4 割遅く、群衆内での歩行による影響が大きく見られる。また、フェ 一ズ毎の歩行速度については、I フェーズ被験者の歩行速度が平均 $0.78 \mathrm{~m} /$ 秒 $(\mathrm{SD}=0.00) 、 \mathrm{II}$ フェーズ被験者の歩行速度が平均 $0.66 \mathrm{~m} /$ 秒 $(\mathrm{SD}=0.13) 、 \mathrm{III}$ フェーズ被験者の歩行速度が平均 $0.40 \mathrm{~m} /$ 秒 $(\mathrm{SD}=0.02)$ となっている。そのうち、II フェーズ上層階（21～24 階）被験者の 歩行速度が平均 $0.57 \mathrm{~m} /$ 秒 $(\mathrm{SD}=0.04) 、$ II フェーズ下層階 $(7 \sim 12$ 階 $)$ 被験者の歩行速度が平均 $0.73 \mathrm{~m} /$ 秒 $(\mathrm{SD}=0.13)$ となっており、特に II フェーズ上層階の被験者は $12 \sim 13$ 階で平均 $0.22 \mathrm{~m} /$ 秒 $(\mathrm{SD}=0.03)$ と低いが、これは後述するように下の階で発生した合流の影響によ り III フェーズの被験者の歩行速度が $14 \sim 18$ 階で平均 $0.12 \mathrm{~m} /$ 秒 （SD=0.05）まで低下していることが影響したものである。

\section{31 階階段室出口の流動係数}

1 階の階段室出口における時刻毎の流動係数を図 4 に示す。図 4 は、1 階階段室出口のビデオ映像から、屝通過人数を 1 秒ごとに目 視でカウントし、15 秒ごとに集計した流動係数を時系列に表した。 なお、1 階階段室から屋外一出る部分や建物前広場においては、混 雑などにより避難者の移動が停止する様な状況は見られず円滑であ り、階段室内の流動に影響のない状態であった。1 階階段室出口で の流動係数は、最大 1.27 人 $/ \mathrm{m} /$ 秒となっている。また、 15 時 22 分 15 秒以降大きな流動低下はなく、15 時 22 分 15 秒から 15 時 37 分 45 秒までの流動量を定常 (一定) と見なすと、平均 0.88 人 $/ \mathrm{m} /$ 秒 $(\mathrm{SD}=0.17)$ となっている。これは、実際の避難訓練時の一般的な流 動係数を示すものと考えられる。

\section{4 階段室内の流動係数}

階段室内の流動状況を把握するため、避難者の多い階の代表とし て 11 階、13 階の流動係数を算出した。流動係数の測定位置は、図 5 に示寸階踊り場における 3 つの断面（上階からの流入断面 A、附 室からの流入断面 B、下階一の流出断面 C) とし、以下 $\mathrm{A} 、 \mathrm{~B} 、 \mathrm{C}$ 断面 と呼ぶものとする。なお、流動係数の算出にあたっては、各階の階 踊り場のビデオ映像から、各断面の通過人数を 1 秒ごとに目視で力 ウントした。

\section{4.1 合流時の流動係数}

合流時の状況を把握寸るため、図 5 の上階からの流入断面 A と附 室からの流入断面 B の流動係数を算出した。11 階の階踊り場につい て、15 秒ごとに集計した流動係数を時系列で表したものを図 6 に示 す。11階の階踊り場では、A および B 断面からの避難者が II フェー ズ避難開始直後から 278 秒間合流（図 6 中の 15 時 16 分 30 秒から 15 時 21 分 8 秒） し、A 断面からは流動係数が平均 0.31 人 $/ \mathrm{m} /$ 秒 $(\mathrm{SD}=0.14) 、 \mathrm{~B}$ 断面からは流動係数が平均 0.45 人 $/ \mathrm{m} /$ 秒 $(\mathrm{SD}=0.23)$ の流入であった。合流解消後の 15 時 21 分以降、 $\mathrm{A}$ 断面の流動係数 は平均 0.71 人 $/ \mathrm{m} /$ 秒 $(\mathrm{SD}=0.24)$ と約 2 倍まで増加しており、流動係

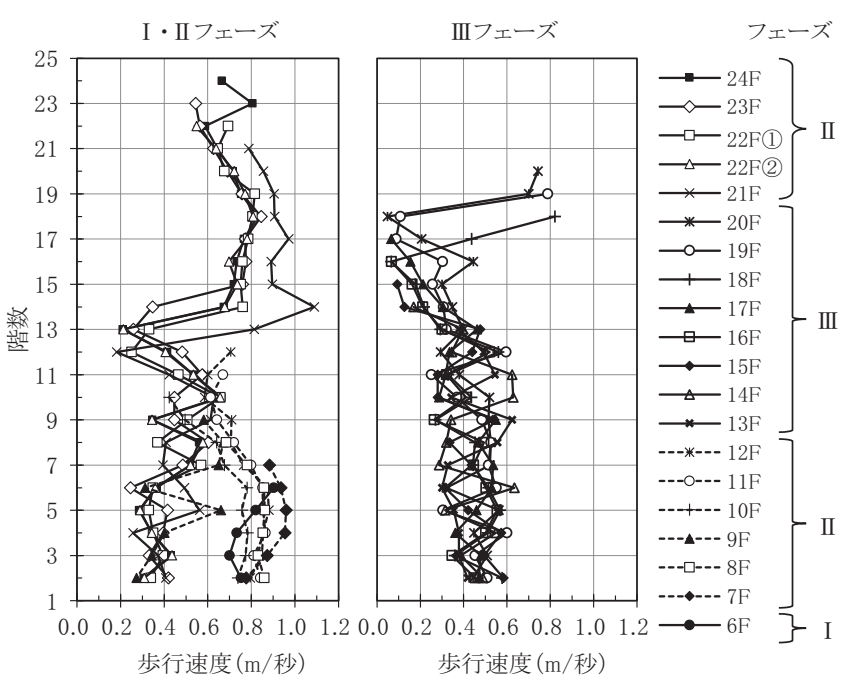

図 3 避難訓練時における各階からの被験者の歩行速度

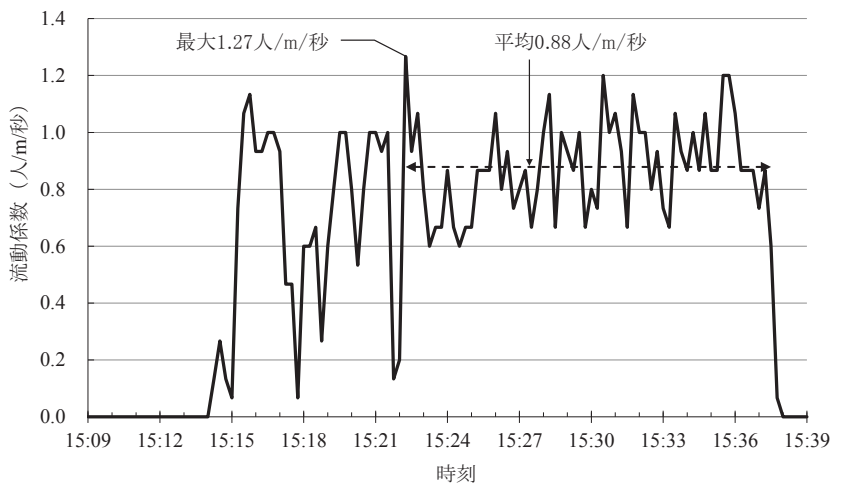

図 41 階階段室出口の流動係数

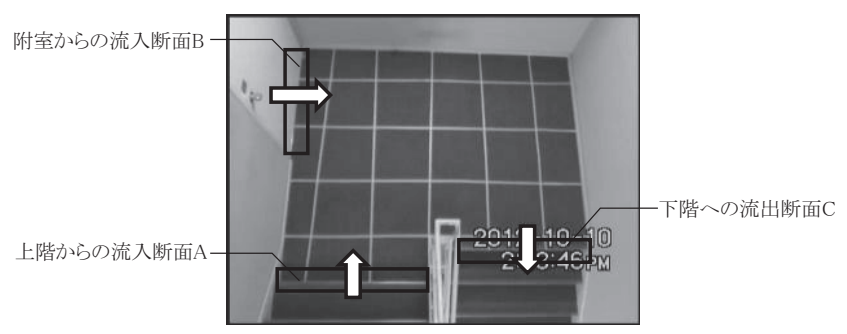

図 5 階段室内の流動係数測定位置（階踊り場）

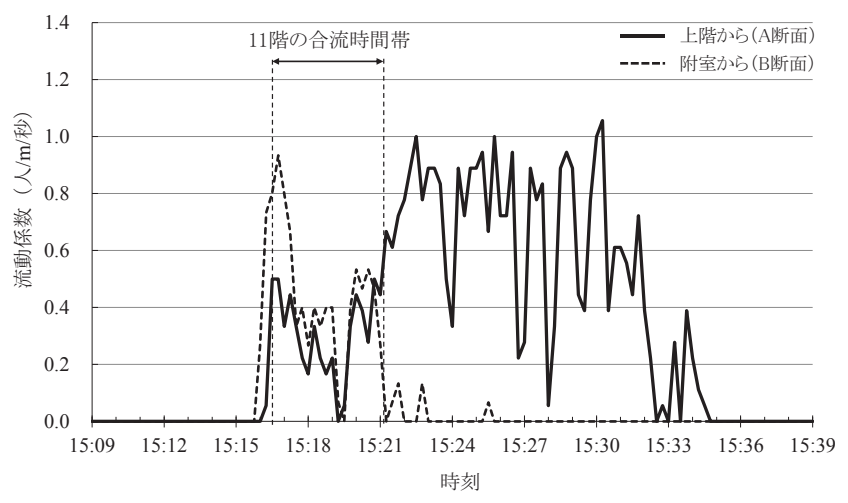

図 6 合流時の流動係数（11 階） 
数が $0.9 \sim 1.0$ 人 $/ \mathrm{m} /$ 秒程度まで増加すると再び減少するように、そ の後増減を繰り返している。合流時間帯においては、上層階からの 歩行者は内側に 2 列から 1 列、附室から階段室内一の歩行者は外側 に 1 列になり合流している。

\section{4.2 複数階にわたる流動係数}

複数階にわたる流動状況を把握するため、ここでは 13 階から 15 階における図 5 に示寸下階への流出断面 C の流動係数を算出した。 13 階から 15 階までの階踊り場について、15 秒ごとに集計した流動 係数を時系列で表したものを図 7 に示す。13 階の合流時間帯（図 7 中の 15 時 21 分 25 秒から 15 時 25 分 3 秒) では、複数階にわたる流 動係数の変化が見られた。12 階の合流は生じておらず、13 階の階踊 り場から 12 階への流動係数は平均 0.76 人 $/ \mathrm{m} /$ 秒 $(\mathrm{SD}=0.17)$ となっ ている。その時、14 階の階踊り場から 13 階への流動係数は平均 0.38 人 $/ \mathrm{m} /$ 秒 $(\mathrm{SD}=0.17)$ と半減している。また、14 階においても合流が 生じており、15 階の階踊り場から 14 階一の流動係数は平均 0.19 人 /m/秒（SD=0.14）と更に半減している。このように合流が生じた階 の上階では流動倸数が半減しており、合流が流動を阻害する要因と なっているとともに、その影響(約 1/2) は上階になるほど累乗的に 及んでいる。

\section{5 階段室内の密度と流動状況}

\section{5.1 階踊り場の密度}

階段室内の混雑状況を把握するため、図 8 に 11 階、図 9 に 13 階 の階踊り場の時刻毎の密度を示す。ここでは、 1 秒ごとの A 断面と B 断面における通過人数の累積量から C 断面における通過人数の累積 量の差をとることにより、階踊り場内の人数を算出し、図 2 (b) に示 す階踊り場の面積を用いて密度を算出した。11 階の密度は、合流が 生じている間に平均 2.49 人 $/ \mathrm{m}^{2}(\mathrm{SD}=0.53)$ 、最大 3.57 人 $/ \mathrm{m}^{2}$ (階踊 り場内に 19 人）となっている（図 8 )。合流解消後には平均 1.44 人 $/ \mathrm{m}^{2}(\mathrm{SD}=0.47)$ まで減少しているが、C 断面の流動係数が低下し た場合に密度が高くなることがわかる。同様に 13 階の密度は、合流 が生じている間に平均 2.36 人 $/ \mathrm{m}^{2} \quad(\mathrm{SD}=0.42)$ 、最大 3.38 人 $/ \mathrm{m}^{2}$ (階 踊り場内に 18 人）となっている（図 9 )。合流解消後には平均 1.51 人 $/ \mathrm{m}^{2}(\mathrm{SD}=0.61)$ まで減少している。なお、図 8 、図 9 に一時的な ピーク值が見られるが、この影響については 4.2 節で述べる。

\section{5 .2 階段室 1 層内の人数}

階段室 1 層分の混雑状況を把握寸るため、図 10 に 11 階、図 11 に 13 階の時刻毎の階段室 1 層内と階踊り場の人数をそれぞれ示す。 なお、階段室 1 層内の人数の算出については、 1 秒ごとの上階 $\mathrm{C}$ 断 面の通過人数の累積量から、当該 $\mathrm{C}$ 断面の通過人数の累積量の差を とることにより、階段室 1 層内の人数を算出した。階踊り場内の人 数については、3.5.1 項の算出によるものとした。また、階段部 と中間踊り場の人数は、階段室 1 層内の人数と階踊り場の人数の差 によるものとした。11階階段室の階踊り場人数は最大 19 人、11〜 12 階の階段部と中間踊り場人数は最大 31 人、階段室 1 層内の人数 は最大 44 人となっている（図 10)。階踊り場の最大人数（19人）と 階段部と中間踊り場の最大人数（31 人）を合わせると 50 人である が、実際の階段室 1 層内の最大人数は 44 人となっている。これは、 階段室内容量の制約のもと、階踊り場や階段部がそれぞれ同時に 個々の最大值とはならないことによるものである。同様に 13 階階段 室の階踊り場人数は最大 18 人、13〜14 階の階段部と中間踊り場人
数は最大 35 人、階段室 1 層内の人数は最大 48 人となっている（図 11)。

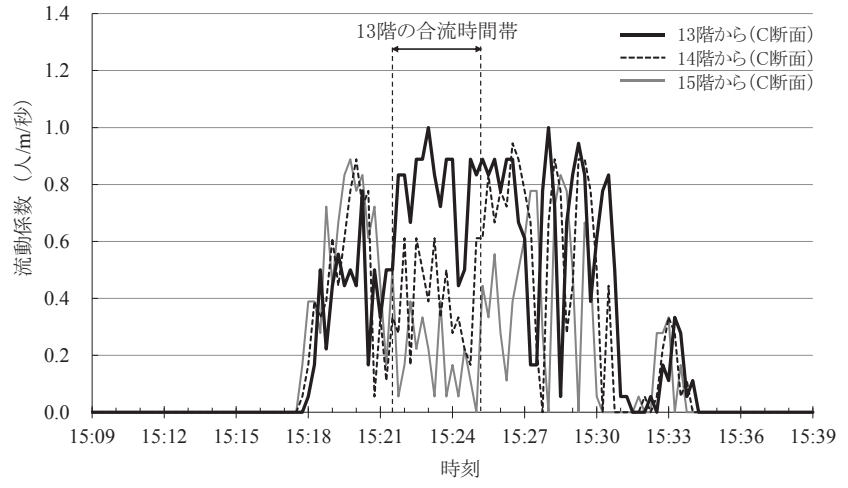

図 7 複数階にわたる流動係数（13～15 階）

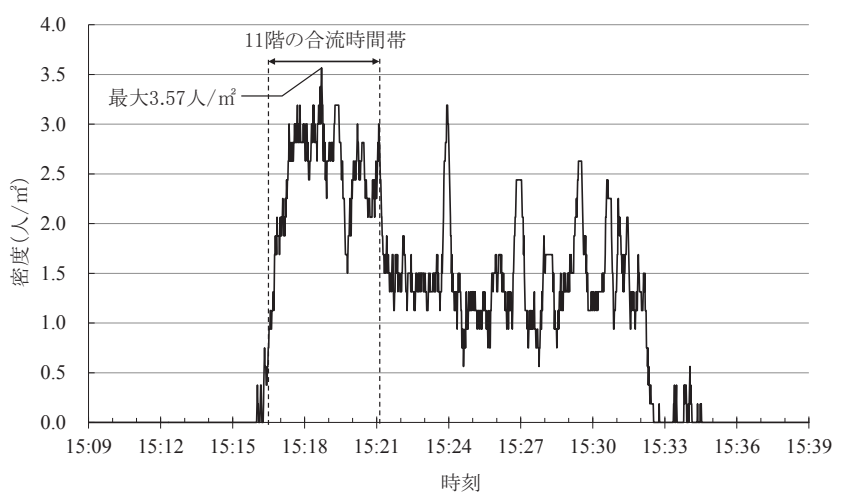

図 8 階踊り場の密度（11 階）

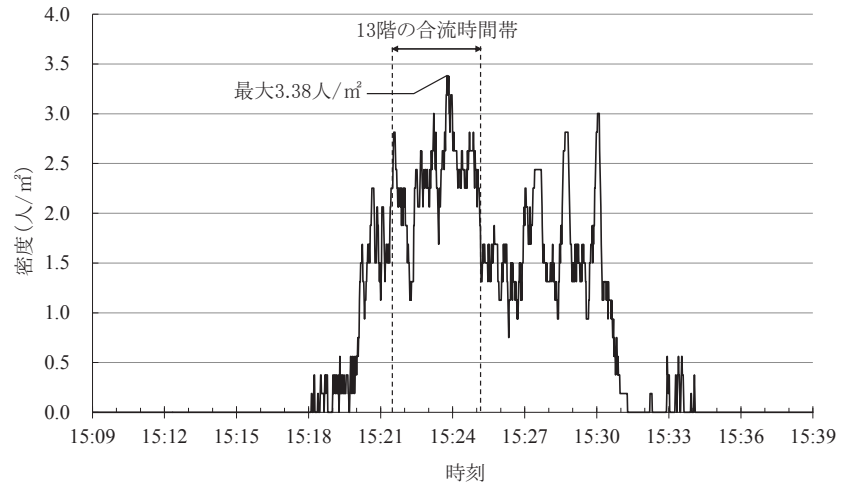

図 9 階踊り場の密度（13 階）

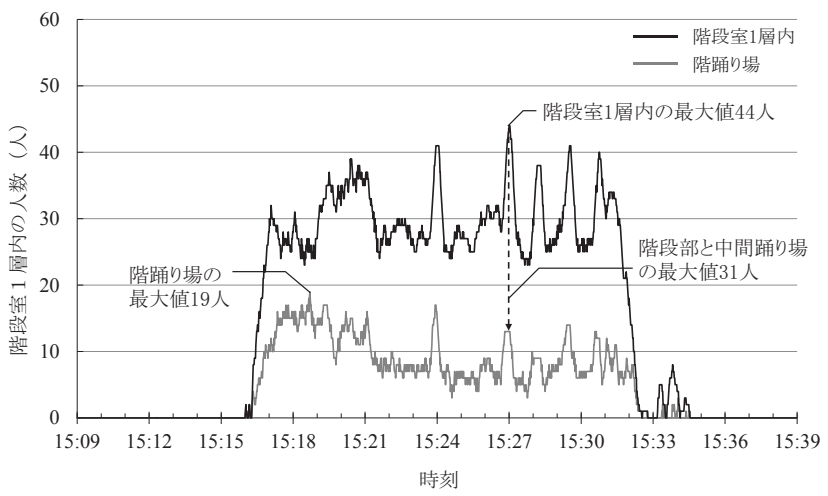

図 10 階段室 1 層内の人数（11 階） 


\section{5.3 階段室 1 層内の密度と流動係数}

階段室内の滞留状況を把握するため、下階の合流の影響が比較的 少なく、流動時間の長い 11 階階段室 1 層内の密度と流動係数の関係 を調べた。図 12 は、 1 秒ごとの階段室 1 層内の密度と C 断面の流動 係数の同時刻值 (階段室 1 層内への流入が見られる 15 時 16 分 1 秒 から 15 時 34 分 46 秒) をプロットしたものである。ここでの密度は、 図 2 (b) に示寸階段室 1 層の水平投影面積により算出した。また、流 動係数の測定位置は、図 5 における階踊り場から下階への流出断面 Cとし、15 秒間の移動平均值とした。

一般に、密度が増加するにつれて流動量は増加するが、一定の密 度になると流動量が限界に達し、流動量が低下寸ることが知られて いる ${ }^{8)}$ 。そこで、既往研究である J. L. Pauls ${ }^{5)}$ による階段室内にお ける一斉避難時の式 $\left(N=1.26 \rho-0.33 \rho^{2}\right)$ を参考にし、原点を通 過する二次曲線で近似を試みた。 $N$ : 流動係数 $(人 / \mathrm{m} /$ 秒)、 $\rho$ : 階段 室 1 層内の密度 $\left(人 / \mathrm{m}^{2}\right)$ とした場合における 11 階階段室 1 層内の 密度と流動係数の関係を式 (1) に表し、図 12 に実線で示す。決定 係数は $\mathrm{R}^{2}=0.61$ である。

$$
N=1.26 \rho-0.48 \rho^{2}
$$

（1）式によると、階段室 1 層内の密度が 1.31 人 $/ \mathrm{m}^{2}$ (22. 33 人) の時、流動係数は 0.83 人 $/ \mathrm{m} /$ 秒と最大值を示している。また、図 12 からも、この密度を境にして流動係数が減少しており、概ね密度が 2.24 人 $/ \mathrm{m}^{2}$ (38 人) となると流動量が無くなり、滞留していること がわかる。その後、密度は 2.60 人 $/ \mathrm{m}^{2}$ (44 人) まで増加している。 これは、実際の避難訓練時の一般的な密度の上限を示すと考えられ る。なお、この值は図 8 の階踊り場のみの密度に比べ低い值を示し ているが、これは階段室全体では階段部の密度を含むためである。

\section{4. 順次避難における階段室内の滞留発生状況}

本避難訓練では、予め計画した順次避難計画に従い、避難放送を 実施している。そのため、II フェーズ上層階からの避難者と、III フ ェーズの避難開始者との合流は概ね避けることができたが、II フェ 一ズ上層階の最後尾の避難者で部分的には生じる結果となった。

図 13 は、各階から避難を開始した訓練参加者（被験者 20 名と従 業員 3 名 (24 階、22 階、12 階の最後尾)）が各階を降下した軌跡を 時系列で表したものである。図中の破線は、避難開始階と避難放送 時間の範囲を表す。被験者の各階階踊り場（A 断面）通過時刻は、 ビデオ映像から被験者が階踊り場に着地した時刻を確認し、これに ストップウォッチにより測定した各階の所要時間を加え求めた。ま た、合流の状況を確認寸るため、階避難者の最後尾が判らない一部 の階（24 階、22 階、12 階）については、ビデオ映像から最後尾の 従業員の通過時刻を求め、図中に加えた。

訓練参加者のうち、22 階から先頭集団の後について避難開始した 者（図 13 中の 22 階避難者(1) については、13・14 階避難者の避難 開始前に 13〜14 階を通過しているため、合流の影響がなかったが、 同階からの避難者の最後尾に付いて避難開始した者（図 13 中の 22 階避難者(2)）は、13・14 階避難開始後の避難となったことから、13 階から 15 階付近の合流の影響を受けていることがわかる。また、図 14 は、IIIフェーズ避難開始後（15 時 23 分 00 秒）の各階の階踊り場 の様子を示寸映像であるが、13 階から上層階で滞留が生じているこ とが確認できる。

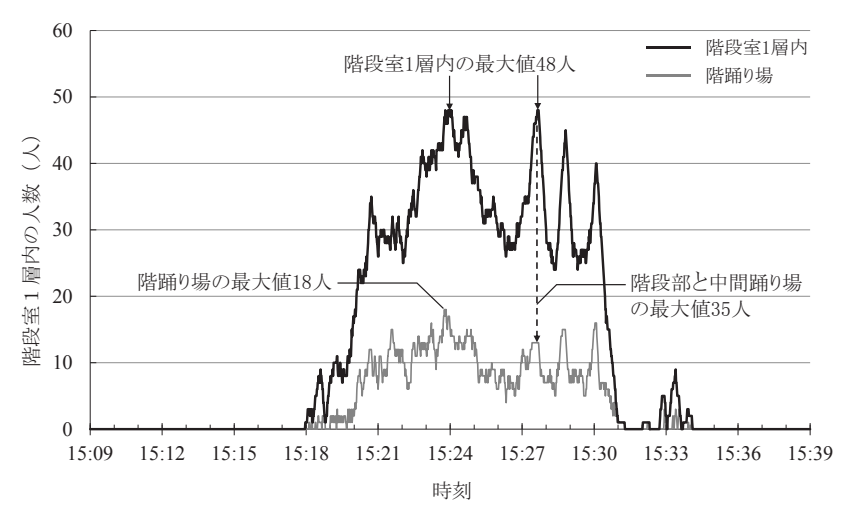

図 11 階段室 1 層内の人数（13 階）

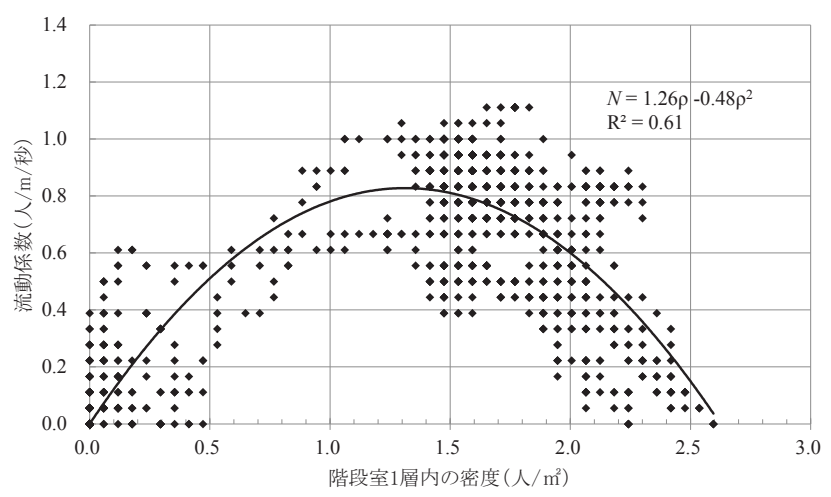

図 1211 階階段室 1 層内の密度と流動係数の関係

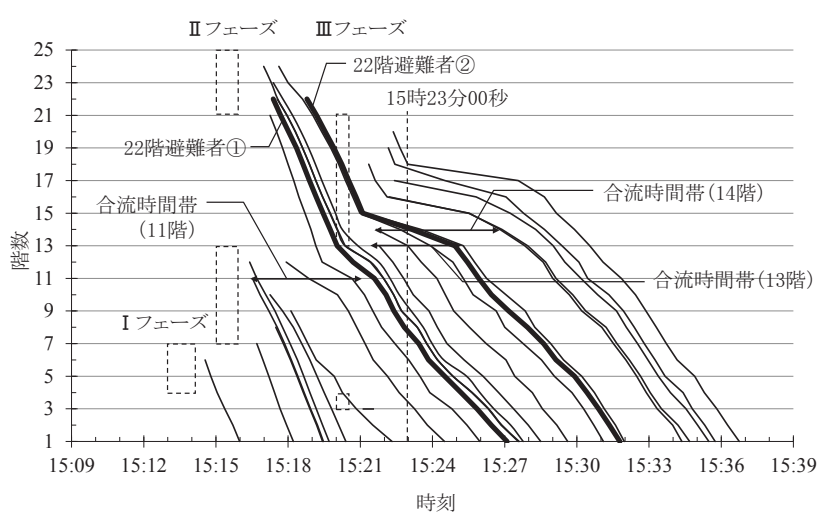

図 13 訓練参加者による各階の通過時刻

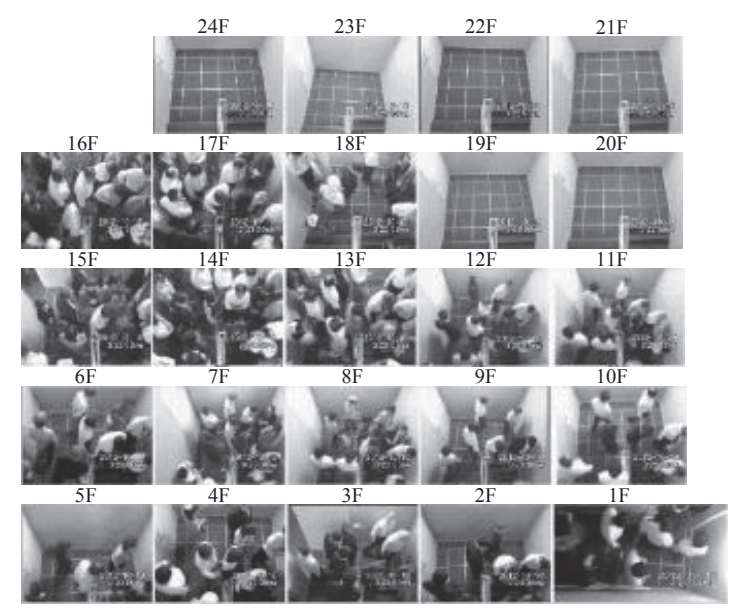

図 14 各階の階踊り場の混雑状況 (15 時 23 分 00 秒) 
以上の訓練観測結果より、合流時と合流解消後の流動量の減少と 密度上昇 (図 6、図 8、図 9)、合流時の複数階にわたる流動量の減 少の伝播（図 7 ）、流動量と密度の関係（図 12）を確認しているこ とから、今回の避難訓練では次の 2 種類の滞留が生じていると考え られる。4.1節から 4.3 節においてその滞留要因の考察を行なう。 (1)合流を原因とする滞留

避難者の多い階（11、13、14 階）について、階段室内への流入者 と上階避難者の合流から滞留が生じ、この滞留が上層階に向かって 伝播していく傾向が見られた。

(2)階段室内の高密状態を原因と寸る滞留

合流を原因とするものだけでなく、階段室内の高密状態から生じ た一時停止が上層階に向かって滞留状態として伝播していく現象が 生じている。

\section{1 合流を原因とする滞留}

図 15 は、図 13 の訓練参加者の各階の通過時刻図をもとに、避難 者の合流による滞留状況を時系列に表したものである。滞留につい ては、各階の階踊り場のビデオ映像より、断続的な停止状態が発生・ 解消した時刻をもとに算出した。なお、図中の右上がりの斜め太線 は、降下歩行速度が低下し、滞留が生じた状況が上階に伝播する様 子を表している。

階段室内の階踊り場内への流入者と上階避難者との合流が生じた 階は、先に述べたように上階からの避難者の流動量が累乗的に減少

（約 1/2）し、これに起因する滞留状況が上層階に向かって伝播し ていることがわかる。階段室内の合流は、II フェーズ内 11 階と上階 （12 階から 15 階まで伝播）、III フェーズ内の 3 階と上階（4 階から 8 階まで伝播) および 13 階、14 階の上階 (15 階から 18 階まで伝播) で生じている。階踊り場内で連続停止した最大滞留時間は、14 階約 27 秒、15 階約 45 秒、16 階約 65 秒、17 階約 125 秒間、18 階約 127 秒間と上階にいくにしたがって順に大きくなっている。

\section{2 階段室内の高密状態を原因とする滞留}

階階段室内では、上記の合流を原因とするものだけでなく、下階 の高密状態が伝播することにより滞留する状況が見られた。合流解 消後、流動量の増加に伴い一定の密度となったが、下階の高密状態 が伝播し、歩行速度が低下し停止状態となることで階段室内の密度 が一時的に増加した。これは、図 8 、図 9 に示すように流動量が低 下した際に、階段室内の密度の断続的な変化がノコギリ歯状のピー ク值としてあらわれ、滞留が生じていたことが確認できる。その滞 留は、上層階に向かって伝播し、階段室内での滞留を生じている。 図 16 は、図 15 同様に図 13 をもとに、高密状態を原因と寸る滞留状 況を時系列に表したものである。滞留は 10 回程起こっており、平均 8 階層（最大 2 階から 16 階までの 15 階層）、上階に伝播している。 これらの滞留は、平均 15.2 秒間隔で上階に伝播している。また、各 階では、短時間であるが滞留から平均 12.2 秒後、停止状態が解消し ている。

\section{3 滞留発生要因に関する考察}

合流を原因とする滞留については、訓練参加者が多い複数階(11、 13、14 階に 100 人以上の訓練参加者が集中）で生じている。階踊り 場では、上階からの避難者は内側に 2 列から 1 列、階段室内一の避 難者は外側に 1 列になり合流している。そのため、合流が生じた階 の上階では流動係数が半減しており、上階に従って流動量が累乗的
に減少（約 1/2）し、滞留が生じている。上階は下階の移動後に移 動するため、上階に従って滞留が長く生じており、最大滞留時間は 18 階で約 2 分間生じている。

一方、高密状態を原因とする滞留については、合流終了後にこの 滞留が伝搬する現象が見られ、流動量と階段室内の人数が上昇した。 これは、安全性を保つため、避難者間の距離をあけながら避難する ために起こっていると考えられる。その結果、1 層あたりの階段室 内の密度が 2.24 人 $/ \mathrm{m}^{2}$ (38 人) 以上になると、短時間ではあるが、 階踊り場で平均 12.2 秒の滞留が生じている。

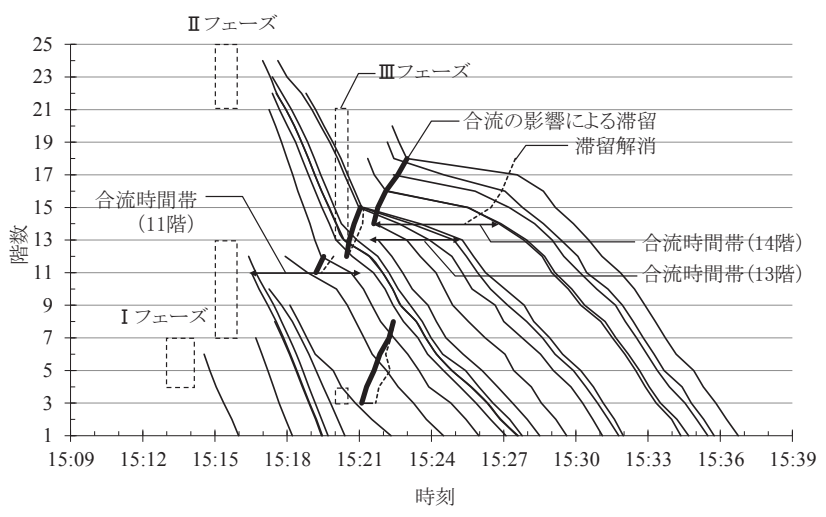

図 15 合流を原因とする帯留

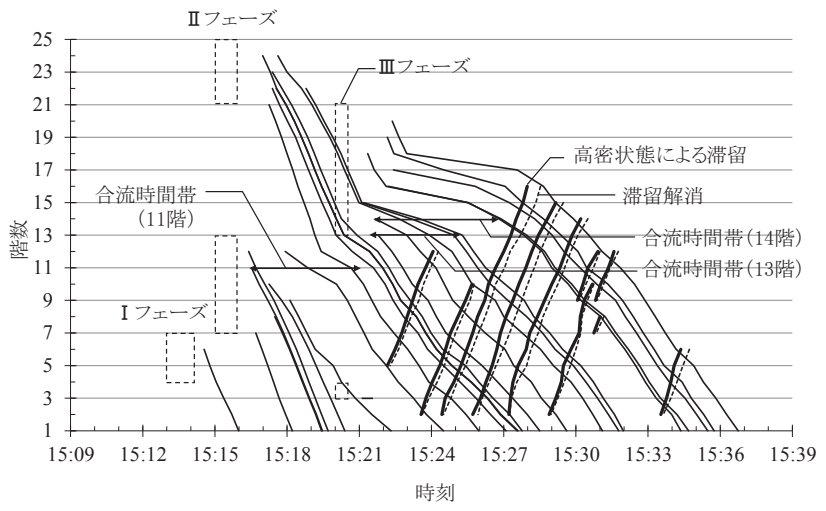

図 16 高密状態を原因とする帯留

\section{5.まとめ}

本研究では、都内の 25 階建て高層建築物で実施された多人数が参 加する全館避難訓練における訓練参加者の行動を観測した結果をも とに、階段室内の流動状況や階段室内で生じる滞留発生状況の分析 とその要因に関する考察を行なった。以下に、その結果を要約する。

(1) 密度と流動係数の関係

11 階の階段室 1 層内の密度 $\rho\left(\right.$ 人 $\left./ \mathrm{m}^{2}\right)$ と流動係数 $N($ 人 $/ \mathrm{m} /$ 秒 $)$ の関係として、 $N=1.26 \rho-0.48 \rho^{2}$ となる近似式 (1) が得られた。 流動係数が最大值となる密度 1.31 人 $/ \mathrm{m}^{2}$ を境にして流動量が減少し ており、密度が 2.24 人 $/ \mathrm{m}^{2}$ (38 人) となると滞留が発生しているこ とがわかった。

（2）階段室内の滞留発生とその要因

今回の避難訓練観測結果から、次の 2 種類の滞留の発生が確認さ れた。1つは、合流を原因とする滞留であり、複数階から 100 人以 
上の避難者が合流した場合、合流が生じた階の上階での流動量の減 少（約 $1 / 2 ）$ が累乗的に上階に伝播することを要因として発生する ものである。もう 1 つは、階段室内の高密状態を原因とする滞留で あり、多層にわたり階段室 1 層内の密度が概ね 2.24 人 $/ \mathrm{m}^{2}$ (38 人) 以上になると発生し、やはりこの滞留も上層階に向かって伝播して いる。なお、合流を原因とする滞留の場合には停止時間が長く（約 2 分間)、一方、高密度状態を原因とする滞留では停止状態は短時間 (平均 12.2 秒間) で解消していた。

最後に、本研究は、都内の高層建築物において 2012 年に実施され た避難訓練の観測結果に基づきまとめたものである。順次避難を含 む全館避難計画の確立に向けては、避難者対象者数、出火階の位置、 順次避難の枠組みなど、種々の条件の変化に応じた詳細な検討が必 要である。したがって、今後も引き続き、順次避難計画を用いた避 難実訓練の調查を行い、安全かつ効率の良い順次避難計画の構築を 目指したいと考えている。

\section{謝辞}

本研究に対し、避難訓練の実測調查に協力して頂いた皆様方と避 難訓練に参加された学生諸氏に心から感謝の意を表します。

\section{参考文献}

1）関澤愛, 佐野友紀, 門倉博之: 高層建築物の全館避難時における階段歩 行に関する研究, 日本建築学会大会学術講演梗概集, A-2, pp. 29-30, 2009.7

2）門倉博之, 関澤愛, 佐野友紀, 大岩大祐, 矢嶋雅倫 : 高層事務所ビルの 全館避難訓練時における階段歩行に関する実測調査とその分析その 3-順 次避難訓練における各階被験者の移動プロファイル分析一, 平成 23 年度日 本火災学会研究発表会概要集, pp. 242-243, 2011.5

3）門倉博之, 関澤愛, 佐野友紀, 矢嶋雅倫, 増田誠良 : 高層事務所ビルの 全館避難訓練時における階段歩行に関する実測調查とその分析その 5一順 次避難訓練における被験者移動プロファイルと流動性状の分析一, 平成 24 年度日本火災学会研究発表会概要集, pp. 136-137, 2012.5

4) J. L. Pauls : Evacuation and Other Fire Safety Measures In High-Rise Buildings, NATIONAL RESEARCH COUNCIL OF CANADA, ASHRAE TRANSACTIONS, Vol.81, Part1, pp.528-534, 1975

5) J. L. Pauls : Calculating Evacuation Times for Tall Buildings, Fire Safety Journal, Vol.12, Issue 3, pp.213-236, 1987.12

6）北後明彦，久保幸資，室崎益輝：階段室における 2 群集の合流に関する 実験的研究, 日本建築学会計画系論文報告集, No. 358, pp. 34-43, 1985.12

7）佐野友紀, 竹市尚広, 木村謙, 大宮喜文, 吉田克之, 渡辺仁史：高層建 築物避難を想定した階段室における在館者群集の合流特性, 日本建築学会 計画系論文集, No. 598, pp. 51-56, 2005. 12

8）J.J.Fruin：歩行者の空間一理論とデザインー, pp. 50-51, 鹿島出版会, 1974 


\section{STUDY ON FLOW AND CONGESTION IN STAIRCASES DURING PHASED EVACUATION IN A HIGH-RISE BUILDING}

- Analysis based on the observational data of a real total evacuation drill -

\section{Hiroyuki KADOKURA* , Ai SEKIZAWA **, Tomonori SANO *** and Kosuke FUJII****}

\footnotetext{
* Tokyu Research Institute, Inc., M. of Sciences in GITS.

* Prof., Tokyo University of Science, Dr. Eng.

*** Prof., Waseda University, Dr. Eng.

**** Waseda University, M.A. in Human Sciences
}

When a large-scale fire or other serious emergency situation were to occur in a high-rise building, it becomes reality that all occupants are forced to evacuate simultaneously and totally from the building at the same time. In order to avoid congestion by simultaneous total evacuation in the stairs, an idea of so-called "Phased Evacuation" has emerged as a feasible evacuation strategy, where occupants on the fire origin floor and the floor above evacuate first followed by the other occupants. However, in planning of the phased evacuation, what happens is that there have been limited studies and data so far concerning this method.

This study is to explore potential availability of phased evacuation along with its issues by conducting the measurement survey during a total evacuation drill based on the phased evacuation and analyzing the congestions in the stair cases.

We conducted the measurement survey on the total evacuation drills by the phased evacuation in a high-rise office building (25 stories above the ground) in Tokyo metropolitan area, which was carried out in 2012. The movement of descending occupant flow was monitored and recorded with video cameras set in the staircase on every floor and the descending time profile of representative occupants on each floor was watched and recorded by our staffs assigned to each floor. The number of participants in this total evacuation drill, who used one of the two emergency stairs for their evacuation drill and observed by our staff was 1,137 . This enabled us to make a comparative analysis about the flow condition of occupants who participated in the evacuation drill over plural floors and to consider possible occurrence factors of congestion in the stairs.

By the analysis of walking speed, flow rates, and the density of occupants in the stairs of each floor, we identified that there are the following two types of congestions.

1) Congestion caused by merging of flows from the floor and from the upstairs

On the floors with large number of occupants, the occupants who entered the stair-case from vestibule merged with the descending occupants from the floor above, where quantity of flow decreased by half resulting in a congestion in the stairs which was sequentially propagated to upper floors. This congestion happened on the 13th (122 people) and 14th (106 people) floor with a lot of evacuees over 2 stories in particular, and it lasted for at most about 2 minutes from the 15 th to the 18 th floor.

2) Congestion caused by high density of occupants inside the staircase

After occupants on all floors started to evacuate, the congestion arose inside the staircase due to high-density condition inside the staircase where the flow rate increased. This congestion was found to spread toward the floors above. When the density in one story of stair case became 2.24 person $/ \mathrm{m}^{2}$ (38 people) or more, the congestion was formed. Approximately 10 times congestion occurred, and it was propagated from the 2nd floor to the 16th floor at intervals of average 15.2 seconds and was dissolved in an average of 12.2 seconds.

In the last, in order to prevent a long congestion in the staircase caused by high density, an appropriate evacuation strategy for the total evacuation in a high-rise building must be examined by further study including an observation of a real evacuation drill, questionnaire survey to participants to the drill, and case studies by using an evacuation simulation model of phased evacuation while changing the conditions of the number of floors and evacuees, location of fire origin floor, and a framework of phased evacuation, etc. 